International Journal of Diabetology \& Vascular Disease Research(IJDVR)

ISSN 2328-353X

\title{
The Diabetic Foot Syndrome an Ignored and Potential Problem in Medical Practice
}

Aziz KM

Editorial

${ }^{1}$ Diabetologist \& Diabetes Research Scientist, Aseer Diabetes Center, Aseer Central Hospital, Ministry of Health, Abha, Saudi Arabia.

\section{*Corresponding Author:}

Dr. Kamran Mahmood A. A. Aziz.

Diabetology Clinic, Aseer Diabetes Center of Aseer Central Hospital, Ministry of Health, P. O. Box 34, Abha, Saudi Arabia.

Tel: 1284-2251155.

E-mail: drkamran9999@yahoo.com

Received: August 26, 2013

Published: September 11, 2013

Citation: Aziz KM (2013) The Diabetic Foot Syndrome an Ignored and Potential Problem in Medical Practice. Int J Diabetol Vasc Dis Res. 1(3e), 1-3. doi: http://dx.doi.org/10.19070/2328-353X-130003e

Copyright: Aziz $\mathbf{K M}^{\odot}$ 2013. This is an open-access article distributed under the terms of the Creative Commons Attribution License, which permits unrestricted use, distribution and reproduction in any medium, provided the original author and source are credited.

\section{Background of the Problem}

Diabetes mellitus is emerging as a global problem and burden [1]. Like other complications of diabetes, diabetic foot problems are posing a health burden worldwide as well. This was the reason that International Diabetes Federation (IDF) has specifically focused on diabetic foot problems throughout the year 2005 and for which worldwide campaign to "put feet first" was held. Currently foot ulceration and its related problems has become common is, affecting up to $15 \%$ of patients with diabetes during their lifetime $[2,3]$. Over $85 \%$ of lower limb amputations are preceded by foot ulcers and diabetes remains the most common cause of nontraumatic amputation in western world [4]. Furthermore, diabetes is now the most common cause of Charcot neuroarthropathy in Western world, which is again preventable[5]. By reviewing the diabetes history and Prior to 1980, it was thought that diabetic foot problems were due to be predominantly vascular and complicated by infection. Later on amputations were performed on patients with diabetes and osteomyelitis but found good blood supply on ulcer site $[6,7]$. Hence now diabetic foot problem is considered a complex and heterogeneous disorder and termed diabetic foot syndrome (DFS) with encompassing both neuropathy with vascular entity $[8,9,10,11]$. Only about half of patients actually notice the ulcer or wound themselves, with the majority occurring on the digits. Ill-fitting or poor footwear is among the most common cause of foot ulceration [12,13,14]. Hence Brand once documented, "pain is God's greatest gift to mankind" because loss of pain and sensation (neuropathy) aggravates the pathology to develop foot ulcers and, despite of tissue damage and infection, patients continue walking with improper footwear which further complicates the situation $[5,15]$. Diabetic foot ulceration and amputations were estimated to cost US health care system about $\$ 10.9$ billion in 2001 and $£, 252$ million in UK in
$2003[16,17,18]$. According to the most recent data from US, $\$ 30.6$ billion was spent on diabetic foot complications, ulcers, and amputations [19]. Nonetheless and in busy clinical practice, most of the physicians are unable to examine the diabetic feet properly and to provide education to diabetic patients regarding foot care.

\section{Pathogenesis of diabetic foot ulcers}

Apart from the patients' ignorance, poor footwear and poor hygienic conditions, diabetic neuropathy is the most common cause of foot ulcerations; neuropathy itself is most common form of the long-term complications of diabetes. Most common amongst the neuropathies which cause foot ulcers are chronic sensorimotor distal symmetrical polyneuropathy [20]. This type of neuropathy commonly results in a sensory loss of stocking distribution confirmed on examination by a deficit in the all sensory modalities. Patients may also give history of neuropathic symptoms such as burning/pricking or stabbing pain, and paresthesia especially at night. Hence neuropathy appears to be one of the most important risk factor and pathology for the development of diabetic foot ulceration. Others risk factors include cigarette smoking, dyslipidemia, and peripheral vascular disease (PVD). These all facts can be collected as a model for development of foot ulcers or Rothman model for causation. Both Pecoraro et al. [21] and later Reiber et al. [22] have taken the Rothman model as an explanation for the development of foot ulcers. According to this model, a component cause (e.g., neuropathy) is not sufficient in itself to lead to foot ulceration, but instead when component causes act together, they result in ulceration. Under this model, weight bearing areas (in the presence of dry skin due to neuropathy) are susceptible for callus (hypertrophic hard skin) formation due to repeated friction and trauma. This callus then acts as foreign body with central hemorrhage or necrosis. Plantar callus is the first trigger for the ulcer formation [23]. Similarly, abnormal plantar pressures play also an important role in the pathogenesis of foot ulcers [24]. Thus a combination of sensory and motor neuropathy with altered gait patterns result in the foot deformity or " high risk" neuropathic foot with clawing of the toes, prominent metatarsal heads, Hallux valgus, high arch and small muscle wasting. Advanced stages of neuropathy may lead to Charcot deformity.

In contrast to the neuropathic ulcers (which are usually painless), vascular ulcers are painful, and as a result of peripheral vascular disease (PVD). PVD is a major contributory factor in the pathogenesis of foot ulceration and subsequent major amputations [25]. Common unique symptoms of vascular involvement of lower limbs include claudication (pain in leg/calf by walking and relieved by rest) and rest pain. Patient also may present clinically with non-healing ulcers $[26,27]$. 


\section{Management of diabetic foot ulcers}

\section{Education and prevention}

Patient education in diabetology clinics and medical clinics is an essential component for diabetic foot management. Diabetic patient should know about regular self-inspection of feet, foot hygiene, proper foot wear, about regular examination by chiropody/ podiatry person, and what action to take in case of injury or foot ulcer $[28,29,30]$.

\section{Screening/examination of feet in the diabetology clinics}

First step in prevention is the identification of the "at risk" foot for which annual/bi-annual review is essential in the diabetology or general practitioner clinics. A taskforce of the American Diabetes Association recently has recently proposed "comprehensive diabetic foot examination (CDFE)" for annual review [31]. CDFE includes through inspection of foot such that evidence of past/ present ulcer; foot shape (prominent metatarsal heads/claw toes, hallux valgus, muscle wasting, Charcot deformity); dermatologic (callus, erythema, sweating); neurological (10-g monofilament, vibration testing using $128 \mathrm{~Hz}$ tuning fork, pinprick sensation testing, ankle reflexes); and vascular examination (foot pulses, ankle brachial index,ABI). Most important, presence of callus should alarm the physician that this patient is at high risk of developing ulceration, and callus should be removed by podiatrist or foot care specialist nurse. Callus usually contains central hemorrhage and is a potential site for infection and future ulceration.

\section{Referral to specialist diabetic foot care multidisciplinary team}

Any non-healing chronic wound should be referred to diabetic foot specialist team. This includes endocrinologist/diabetologist, chiropodist or podiatrist, orthopedic surgeon and plastic surgeon (the surgical team) and rehabilitation unit for off-loading, making special foot wear and appropriate medical management of infection and comorbidities or surgical intervention $[32,33,34,35,36,37,38,39]$.

All above described facts about diabetic foot are briefly described in table-1

Table 1. Etiopathology of foot ulcers, types, prevention and treatment in brief

\begin{tabular}{|c|c|c|c|}
\hline \multicolumn{4}{|c|}{ Primary reasons for foot problems in diabetes } \\
\hline Microvascular & \multicolumn{3}{|c|}{ Peripheral neuropathy \& loss of protective sensation } \\
\hline Macrovascular & \multicolumn{3}{|c|}{ Vascular insufficiency/ischemia, peripheral vascular disease (PVD) } \\
\hline Metabolic & \multicolumn{3}{|c|}{ Hyperglycemia } \\
\hline Trauma & \multicolumn{3}{|l|}{ Repetitive and acute, footwear injury } \\
\hline Foot deformities & \multicolumn{3}{|c|}{$\begin{array}{l}\text { Prominent metatarsal heads/claw toes (excess plantar pressures), hallux valgus, hammer toes, bunion, } \\
\text { Charcot deformity }\end{array}$} \\
\hline Dermatologic & \multicolumn{3}{|c|}{ Dry skin, callus, corns, tinea (fungal infection), ulcers $( \pm$ infected $)$} \\
\hline \multicolumn{4}{|c|}{$\begin{array}{l}\text { Types of foot ulcers } \\
\end{array}$} \\
\hline Description & Neuropathic & Ischemic & $\begin{array}{l}\text { Neuro-isch- } \\
\text { emic }\end{array}$ \\
\hline Circulation & Intact/bounding pulses & Decreased/absent pulses & \\
\hline $\begin{array}{l}\text { Site of ulcer and infec- } \\
\text { tion }\end{array}$ & $\begin{array}{l}\text { Pressure/plantar surface; often preceded by } \\
\text { callus formation (with central hemorrhage); } \\
\text { 土sepsis/osteomyelitis }\end{array}$ & $\begin{array}{l}\text { Lesions on the margins of foot, tip } \\
\text { of toes, heels; absence of callus; } \\
\text { 土necrosis/gangrene/osteomyelitis } \\
\text { (pink to blackish discoloration) Criti- } \\
\text { cal ischemia (urgent attention) Pink, } \\
\text { painful, pulseless and often cold foot }\end{array}$ & \multirow[t]{7}{*}{$\begin{array}{l}\text { Sharing both } \\
\text { features of } \\
\text { neuropathic } \\
\text { and ischemic } \\
\text { ulcers }\end{array}$} \\
\hline Pain & $\begin{array}{l}\text { Painless (other symptoms: burning, stabbing, } \\
\text { pricking sensations specially at night }\end{array}$ & Severe pain all over the day and night & \\
\hline Feet temperature & Warm & Not warm/cold & \\
\hline \multirow[t]{4}{*}{ Examination } & \multirow[t]{4}{*}{$\begin{array}{l}\text { 10-g monofilament (to check loss of protective } \\
\text { sensations) vibration perception by } 124 \mathrm{~Hz} \\
\text { tuning fork, pin prick, tendon reflexes }\end{array}$} & $\begin{array}{l}\text { Pulses (dorsalis pedis, posterior tibial, } \\
\text { popliteal); ABI, ankle brachial index, } \\
\text { assessment useful }\end{array}$ & \\
\hline & & Normal : 1-1.3 & \\
\hline & & Ischemia $<1.0$ & \\
\hline & & Calcified $>1.3($ false +$)$ & \\
\hline \multicolumn{4}{|c|}{ Prevention } \\
\hline \multicolumn{4}{|c|}{ Patient Education and foot care advises } \\
\hline \multicolumn{4}{|c|}{ Regular clinical examination of feet } \\
\hline \multicolumn{4}{|c|}{ Planter pressure measurement by special devices } \\
\hline \multicolumn{4}{|c|}{ Therapeutic footwear } \\
\hline \multicolumn{4}{|c|}{ Foot ulcers : Treatment principles (Multidisciplinary team approach) } \\
\hline \multicolumn{4}{|l|}{ Debridement } \\
\hline \multicolumn{4}{|c|}{ Pressure relief (“off-loading”) } \\
\hline \multicolumn{4}{|c|}{ Appropriate wound management } \\
\hline \multicolumn{4}{|c|}{ Management of infection } \\
\hline \multicolumn{4}{|c|}{ Management of ischemia } \\
\hline \multicolumn{4}{|c|}{ Medical management of co-morbidities } \\
\hline Surgical management & & & \\
\hline
\end{tabular}


Globally, diabetic foot complications remain still a major medical, social and economic problems that are seen in every country with varying prevalence $[40,41]$.

There remains an unresolved issue in diabetic foot management which demands further research in diabetic medicine [42]. Diabetes remains a major cause of non - traumatic amputation worldwide with rates being as much as 15 times higher than in the nondiabetic population.

\section{References}

[1]. King H, Aubert RA, Herman WH. Global burden of diabetes, 1995-2025. Prevalence, numerical estimates, and projections. Diabetes Care 1998; 21:1414.

[2]. Reiber GE. Epidemiology of foot ulcers and amputations in the diabetic foot. In: Bowker JH, Pfeifer MA, (Eds) the Diabetic Foot, St. Louis: Mosby; 2001. p. 13-32.

[3]. Reiber GE, Boyko EJ, Smith DG. Lower extremity foot ulcers and amputations in diabetes. In: Harris MI, Cowie C, Stern MP, (Eds). Diabetes in America, 2nd ed, USA: NIH Publication; No. 95-1468; 1995. P.409-27.

[4]. Boulton AJM, Vileikyte L, Ragnarson - Tennvall G, Apelqvist J. The global burden of diabetic foot disease. Lancet 2005; 366: 1719 - 1724

[5]. Boulton AJM. The diabetic foot: from art to science: the 18th Camillo Golgi lecture. Diabetologia 2004; 47: 1343 - 1353.

[6]. Connor H. Some historical aspects of diabetic foot disease. Diabet Metab Res Rev 2008; 24 (Suppl 1): 7 - 13.

[7]. McKeown KC. The history of the diabetic foot. Diabet Med 1995; 12: $19-23$.

[8]. S ä maan A, Tajiyeva O, M ü ller N, Tschauner T, Hoyer H, Wolf G, et al . Prevalence of the diabetic foot syndrome at the primary care level in Germany: a cross - sectional study. Diabet Med 2008; 25: 557 - 563.

[9]. Lavery LA, Armstrong DG, Wunderlich RP, Tredwell J, Boulton AJ. Diabetic foot syndrome: evaluating the prevalence and incidence of foot pathology in Mexican Americans and non-Hispanic whites from a diabetes disease management cohort. Diabetes Care 26:1435-1438, 2003.

[10]. Lobmann R, Schultz G, Lehnert H. Proteases and the diabetic foot syndrome: mechanisms and therapeutic implications. Diabetes Care 28:461471, 2005

[11]. Enderle MD, Coerper S, Schweizer HP, Kopp AE, Thelen MH, Meisner C, Pressler H, Becker HD, Claussen C, Haring HU, Luft D. Correlation of imaging techniques to histopathology in patients with diabetic foot syndrome and clinical suspicion of chronic osteomyelitis. The role of highresolution ultrasound. Diabetes Care 22:294-299, 1999.

[12]. MacFarlane RM, Jeffocoate WJ. Factors contributing to the presentation of diabetic foot ulcers. Diabet Med 1997; 14:867-70.

[13]. Apelqvist J, Larsson J, Agardh CD. The influence of external precipitating factors and peripheral neuropathy on the development and outcome of diabetic foot ulcers. J Diabet Complications 1990; 4:21-5.

[14]. Manna I, Pradham D, Ghosh S, Kar SK, Dhara P. A comparative study of foot dimensions between adult male and female and evaluation of foot hazards due to using of footwear. J Physiol Anthropol Appl Human Sci 2001; 20:241-6.

[15]. Boulton AJM. The diabetic foot: grand overview. Diabet Metab Res Rev 2008; 24 (Suppl 1): 3-6.

[16]. Shearer A, Scuffham P, Gordois A, Oglesby A. Predicted costs and outcomes from reduced vibration detection in people with diabetes in the US. Diabetes Care 2003; 26: 2305 - 2310.

[17]. Gordois A, Scuffham P, Shearer A, Oglesby A, Tobian JA. The health care costs of diabetic peripheral neuropathy in the US. Diabetes Care 2003; 26 : $1790-1795$.

[18]. Gordois A, Scuffham P, Shearer A, Oglesby A. The healthcare costs of diabetic peripheral neuropathy in the UK. Diabet Foot 2003; 6: 62 - 73 .

[19]. Rogers LC, Lavery LA, Armstrong DG. The right to bear legs. J Am Podiat Med Assoc 2008; 98: 166 - 168.
[20]. Boulton AJM, Malik RA, Arezzo JL, Sosenko JM. Diabetic somatic neuropathies: technical review. Diabetes Care 2004; 27: 1458 - 1486.

[21]. Pecoraro RE, Reiber GE, Burgess EM. Pathways to diabetic limb amputation: basis for prevention. Diabetes Care 1990; 13: 510 - 521.

[22]. Reiber GE, Vileikyte L, Boyko EJ , del Aguila M, Smith DG, Lavery LA , et al . Causal pathways for incident lower - extremity ulcers in patients with diabetes from two settings. Diabetes Care 1999; 22: 157 - 162.

[23]. Murray HJ, Young MJ, Boulton AJM. The relationship between callus formation, high foot pressures and neuropathy in diabetic foot ulceration. Diabet Med 1996; 13: 979 - 982.

[24]. Boulton AJM, Kirsner RS, Vileikyte L. Neuropathic diabetic foot ulcers. N Engl J Med 2004; 351: 48 - 55.

[25]. Siitonen OI, Niskanen LK, Laakso M, Siitonen JT, Pyörälä K. Lower extremity amputation in diabetic and non - diabetic patients: a population - based study from Eastern Finland. Diabetes Care 1993; 16: 16 - 20.

[26]. Marso SP, Hiatt WR. Peripheral arterial disease in patients with diabetes. J Am Coll Cardiol 2006; 47: 921 - 929.

[27]. Mostaza JM , Suarez C , Manzano L , Cairols M , López- Fernández F , Aguilar I , et al. Sub - clinical vascular disease in type 2 diabetic subjects: relationship with chronic complications of diabetes and presence of cardiovascular disease risk factors . Eur J Int Med 2008; 19: 255 - 260.

[28]. Mason J, O’ Keeffe C, McIntosh A, Hutchinson A, Booth A, Young RJ. A systematic review of foot ulcer prevention in patients with Type 2 diabetes. 1: Prevention. Diabet Med 1999; 16: 801 - 812.

[29]. Lincoln NB, Radford KA, Game FL, Jeffcoate WJ. Education for secondary prevention of foot ulcers in people with diabetes: a randomized controlled trial. Diabetologia 2008; 51: 1954 - 1961.

[30]. Uccioli L, Faglia E, Montocine G, Favales F, Durola L, Aldeghi A, et al. Manufactured shoes in the prevention of diabetic foot ulcers. Diabetes Care 1995; $18: 1376-1378$.

[31]. Boulton AJM , Armstrong DG, Albert SF , Frykberg RG, Hellman R, Kirkman MS , et al . Comprehensive foot examination and risk assessment. Diabetes Care 2008; 31: 1679 - 1685.

[32]. Armstrong DG, Nguyen HC, Lavery LA, van Schie CH, Boulton AJM, Harkless LB. Offloading the diabetic foot wound: a randomized clinical trial. Diabetes Care 2001; 24: 1019 - 1022.

[33]. Katz IA, Harlan A, Miranda - Palma B, Preto L, Armstrong DG, Bowker $\mathrm{JH}$, et al. A randomised trial of two irremovable offl oading devices in the management of plantar neuropathic diabetic foot ulcers. Diabetes Care 2005; 28: $555-559$.

[34]. Mason J, O’ Keeffe CO, Hutchinson A, McIntosh A, Young R, Booth A. A systematic review of foot ulcers in patients with type 2 diabetes. II: Treatment. Diabet Med 1999; 16: 889 - 909.

[35]. Knowles EA. Dressings: is there an evidence base? In: Boulton AJM, Cavanagh PR, Rayman G, eds. The Foot in Diabetes, 4th edn. Chi Chester: John Wiley \& Sons Ltd, 2006: 186 - 197.

[36]. Lipsky BA. New developments in diagnosing and treating diabetic foot infections. Diabet Metab Res Rev 2008; 24 (Suppl 1): S66 - S71.

[37]. Lipsky BA. A report from the international consensus on diagnosing and treating the infected diabetic foot. Diabet Metab Res Rev 2004; 20 (Suppl 1): $68-77$.

[38]. Lipsky BA, Berendt AR, Deery HG , Embil JM , Joseph WS , Karchmer AW, et al . Infectious Diseases Society of America guidelines: diagnosis and treatment of diabetic foot infections. Clin Infect Dis 2004; 39: 885 - 910

[39]. Berendt AR, Peters EJ , Bakker K, Embil JM , Eneroth M , Hinchliffe RJ , et al . Diabetic foot osteomyelitis: a progress report on diagnosis and a systematic review of treatment. Diabet Metab Res Rev 2008; 24 (Suppl 1): $145-161$.

[40]. Boulton AJM, Vileikyte L. Diabetic foot problems and their management around the world. In: Bowker JH, Pfeifer MA, eds. Levin \& O' Neal's The Diabetic Foot, 7th edn. Philadelphia: Mosby- Elsevier, 2008: 487 - 496.

[41]. Van Houtun WH. Amputations and ulceration: pitfalls in assessing incidence. Diabet Metab Res Rev 2008; 24 (Suppl 1): 14 - 18.

[42]. Jeffcoate WJ, Lipsky BA, Berendt AR, Cavanagh PR, Bus SA, Peters EJ, et al. Unresolved issues in the management of ulcers of the foot in diabetes. Diabet Med 2008; 25: 1380 - 1389. 